\title{
Manufacture of low-fat Cheddar cheese by exopolysaccharide-producing Lactobacillus plantarum JLK0142 and its functional properties
}

\author{
Ji Wang, ${ }^{1}$ Tong Wu, ${ }^{1}$ Xiaobin Fang, ${ }^{1}$ and Zhennai Yang ${ }^{1,2 *}$ \\ ${ }^{1}$ College of Food Science and Engineering, Jilin Agricultural University, Changchun, China 130118 \\ ${ }^{2}$ Beijing Advanced Innovation Center for Food Nutrition and Human Health, Beijing Laboratory of Food Quality and Safety, \\ Beijing Technology and Business University, Beijing, China 130118
}

\section{ABSTRACT}

This study aimed to evaluate the effect of exopolysaccharide (EPS)-producing Lactobacillus plantarum JLK0142 on the ripening characteristics and in vitro health-promoting benefits of low-fat Cheddar cheese. Three batches of cheese were made by employing a nonEPS-producing cheese starter (control), in combination with Lb. plantarum JLK0142 as an adjunct and the purified EPS as an ingredient. Lactobacillus plantarum JLK0142 survived well in cheese, with counts of $7.99 \mathrm{log} \mathrm{cfu} / \mathrm{g}$ after $90 \mathrm{~d}$ of ripening. All experimental cheeses (with adjunct culture or EPS ingredient) had higher moisture, proteolysis, and sensory scores, and lower hardness and cohesiveness compared with the control cheese. Water-soluble extracts from the experimental cheeses outperformed that of the control in scavenging 1,1-diphenyl-2-picrylhydrazyl (DPPH), 2,2'-azino-bis(3-ethylbenzothiazoline-6-sulfonic acid) diammonium salt (ABTS), and hydroxyl radicals, and inhibiting $\alpha$-amylase, angiotensin-converting enzyme, and HT-29 tumor cell growth. Therefore, incorporation of the EPS-producing culture of Lb. plantarum JLK0142 is promising for improvement of low-fat cheese quality and bioactivities.

Key words: exopolysaccharide, Lactobacillus plantarum, low-fat Cheddar cheese, health-promoting benefit

\section{INTRODUCTION}

Consumption of low-fat foods is increasing every year, as ingestion of excess fat may result in an increase in obesity, cancer, and cardiovascular disease. During the last decade, cheese has become one of the most widely used food ingredients, and various types of low-

Received June 4, 2018.

Accepted December 27, 2018.

*Corresponding author: yangzhennai@th.btbu.edu.cn fat cheeses that possess health-promoting benefits beyond their nutritional value have become a way of life for consumers around the world, especially in Western countries and the Chinese mainland (Oluk et al., 2014). However, reducing fat content in cheese by half was found to cause rubbery texture, a lack of flavor, and poor functional properties of cheese (Demers-Mathieu et al., 2016). Although some new technologies were used to improve flavor, texture, and functionality of cheese, research has mainly focused on soft low-fat and fresh cheeses (Romeih et al., 2012). Low-fat, semi-hard, and hard ripened cheeses have not been well studied.

Generally, manufacturing procedures developed to improve low-fat, semi-hard, and hard ripened cheeses include processing techniques, use of additives, and starter culture selection (Amelia et al., 2013; Di Cagno et al., 2014; Khanal et al., 2018). However, technological improvements to cheesemaking processes do not necessarily apply to all cheese plants or cheese types, and they may incur financial costs. The use of additives, such as emulsifying and thickening agents, could improve cheese texture, but they might have adverse effects on flavor formation (Dabour et al., 2005).

Lactic acid bacteria (LAB) are generally used to produce cheese owing to their proteolytic, lipolytic, and glycolytic activities, which are conducive to flavor, texture, nutritional value, and the health-promoting benefits of cheese (Blaya et al., 2018). Many LAB strains are able to produce exopolysaccharides (EPS), which are extracellular high-molecular-weight polymers either attached to the bacterial surface (capsular EPS) or released to the growth environment (ropy EPS; Wang et al., 2015b). The EPS produced by LAB play an important role in the fermentation of dairy products because of their positive effects on rheological and textural properties. For example, the EPS have been used as a thickening agent or stabilizer in low-fat and halffat cheeses to improve textural and rheological properties (Dabour et al., 2006). The use of EPS-producing starters resulted in higher moisture levels, greater rates of proteolysis, and softer textures than those of low-fat 
cheese without EPS-producing starters (Lynch et al., 2014). Ayyash et al. (2018) manufactured low-fat Akawi cheeses with EPS-producing Lactobacillus plantarum starter cultures, which significantly improved the rheological, textural, and sensory properties of the cheese. Costa et al. (2010) showed that cheese made with EPSproducing starter had improved texture and cooking properties without negative effects on the flavor profile of the cheese. In addition to their technological properties, LAB EPS have also attracted much attention owing to their various health-promoting potentials, such as antioxidant, immunoregulatory, antitumor, antibacterial, antidiabetic, and cholesterol-lowering activities (Patten et al., 2014; Dilna et al., 2015; Zhang et al., 2016; Rajoka et al., 2018).

Lactobacillus plantarum exists in a wide range of food niches, including fermented vegetable, plant, dairy, and meat products. Some EPS-producing Lb. plantarum strains isolated from traditional Chinese sauerkraut, Inner Mongolian hurood cheese, and Tibetan kefir have been evaluated for their probiotic properties, as well as their viability after production and storage ( $\mathrm{Li}$ et al., 2012; Zhang et al., 2013a; Wang et al., 2014). In recent years, different EPS-producing LAB, including streptococci, lactobacilli, lactococci, and bifidobacteria, were used as starter or adjunct cultures to manufacture lowfat cheeses including Cheddar, Mozzarella, Tulum, and Akawi (Zisu and Shah, 2007; Oluk et al., 2014; Soda, 2014; Ryan et al., 2015; Al-Dhaheri et al., 2017; Ayyash et al., 2018). However, to our knowledge, the fermentation characteristics and health-promoting benefits of low-fat Cheddar cheese as affected by EPS-producing Lb. plantarum during ripening have not been reported.

In our previous study, a strain designated $L b$. plantarum JLK0142, with robust probiotic properties and EPS-production capability, was isolated from traditional fermented dairy tofu in the Inner Mongolia region of China. Previous results demonstrated that its EPS had strong hydroxyl radical-scavenging activity and could induce apoptosis in human colon cancer HT-29 cells, effectively improving immunomodulatory activity of RAW 264.7 cells to stimulate the immune systems of cyclophosphamide-induced immunosuppressed mice (Wang et al., 2018a).

The objective of the current study was to investigate the effect of using EPS-producing Lb. plantarum JLK0142 as an adjunct culture on various properties of low-fat Cheddar cheese, including chemical and microbiological composition, proteolysis, textural, and sensory properties. We also investigated its health-promoting potentials in vitro, namely antioxidant, $\alpha$-amylase and $\alpha$-glucosidase inhibition, angiotensin-converting en- zyme (ACE) inhibition, and antiproliferative activities in the colon cancer HT-29 cell line.

\section{MATERIALS AND METHODS}

\section{Bacterial Strains and Growth Conditions}

The EPS-producing Lb. plantarum JLK0142 used in our study was stocked in $40 \%$ glycerol at $-80^{\circ} \mathrm{C}$. Before cheese manufacture, $L b$. plantarum JLK0142 was subcultured twice consecutively at $37^{\circ} \mathrm{C}$ overnight in $12 \%$ (wt/vol) sterile reconstituted skim milk and was adjusted to $10^{6} \mathrm{cfu} / \mathrm{mL}$ of cheese milk. A non-EPSproducing Lactococcus lactis ST25 preserved in our laboratory was used as cheese starter culture, and it was activated by growing at least twice consecutively for $7 \mathrm{~h}$ at $30^{\circ} \mathrm{C}$ in $12 \%$ (wt/vol) sterile reconstituted skim milk.

\section{Cheese Manufacture}

Low-fat Cheddar cheeses were produced according to the method of Demers-Mathieu et al. (2016) with slight modifications. Briefly, the homogenized and pasteurized $\left(74.5^{\circ} \mathrm{C}\right.$ for $\left.18 \mathrm{~s}\right)$ low-fat $(1.3 \%)$ bovine milk was maintained at $32^{\circ} \mathrm{C}$. Calcium chloride solution $(45 \%$, $\mathrm{vol} / \mathrm{vol})$ was then added $(0.26 \mathrm{~mL} / \mathrm{kg})$ into the milk. Three batches of cheese were prepared in this study: (A) control cheese made with $1.5 \%$ (wt/vol) inoculum of the cheese starter culture alone; (B) experimental cheese made with $1.5 \%$ (wt/vol) inoculum of the cheese starter culture and $0.2 \%$ (wt/vol) of the purified EPS ingredient from Lb. plantarum JLK0142; and (C) experimental cheese made with $1.5 \%$ (wt/vol) inoculum of the cheese starter culture and Lb. plantarum JLK0142 $\left(10^{6} \mathrm{cfu} / \mathrm{mL}\right.$ of cheese milk). After $40 \mathrm{~min}$ of ripening, double-strength rennet (Chy-Max; Chr. Hansen, Hørsholm, Denmark) dissolved in cold water was added at $0.077 \mathrm{~mL} / \mathrm{kg}$. The curd was cut after $40 \mathrm{~min}$ into cubes of approximately $1-\mathrm{cm}^{3}$ using cheese knives. After 10 min of rest, the cooking step was initiated by gradually raising the temperature to $38^{\circ} \mathrm{C}$ and holding it for 25 min until the $\mathrm{pH}$ of the whey reached 6.2. The whey was then drawn off and the temperature was maintained at $37^{\circ} \mathrm{C}$ during the cheddaring step. During cheddaring, the curd portion was piled and turned over 3 times at 30-min intervals until the $\mathrm{pH}$ reached 5.6. The curds were milled and salted (2\%, wt/wt) before being put into cheese molds and pressed at $4.5 \mathrm{~kg}$ pressure for 15 min, and then pressed at $18.14 \mathrm{~kg}$ pressure overnight. After pressing, $\sim 500$-g blocks of Cheddar cheese were vacuum-packaged and ripened at $4^{\circ} \mathrm{C}$ for 3 mo (Zhang 
et al., 2013b; Liu et al., 2018b). Cheeses were sampled at $0,7,14,30,60$, and $90 \mathrm{~d}$ of storage.

\section{Gross Composition, Water Activity, and $\mathrm{pH}$ Value}

The protein content was determined by the macroKjeldahl method and fat content by the Gerber method, according to AOAC International (2005). Cheese was further analyzed for moisture and salt (Fox, 1963). Water activity was measured by a water activity meter (MB120, Rotronic, Bassersdorf, Switzerland). The pH of a slurry, prepared by macerating $10 \mathrm{~g}$ of grated cheese with $12 \mathrm{~mL}$ of cold deionized water, was measured by using a calibrated $\mathrm{pH}$ meter (FE20 $\mathrm{pH}$ meter, Mettler Toledo, Columbus, OH).

\section{Microbiological Analysis}

Five grams of cheese samples was diluted in $45 \mathrm{~mL}$ of sterile $2 \%$ (wt/vol) trisodium citrate at $40^{\circ} \mathrm{C}$ and homogenized for $2 \mathrm{~min}$ at high speed in a beaker to obtain a slurry for the first dilution; subsequent serial dilutions were performed in $0.09 \%$ (wt/vol) saline solution. A volume of $0.1 \mathrm{~mL}$ of the dilution was spread plated in triplicate on the M17 medium and Lb. plantarum-selective medium. Lactococcus lactis ST25 was enumerated on M17 agar under aerobic condition at $30^{\circ} \mathrm{C}$ for $72 \mathrm{~h}$. Lactobacillus plantarum JLK0142 was enumerated on a $L b$. plantarum-selective medium under anaerobic incubation at $37^{\circ} \mathrm{C}$ for $72 \mathrm{~h}$ (Bujalance et al., 2006).

\section{Assessment of Proteolysis}

Preparation of Water-Soluble Extracts. Watersoluble extracts (WSE) were prepared according to Kuchroo and Fox (1982) by homogenizing $50 \mathrm{~g}$ of grated cheese sample with $100 \mathrm{~mL}$ of deionized-distilled water. The slurries were centrifuged at $8,000 \times g$ for $15 \mathrm{~min}$ at $4^{\circ} \mathrm{C}$, after which they were filtered through a $0.22-\mu \mathrm{m}$ pore size filter to obtain WSE. The WSE was then lyophilized and stored at $-20^{\circ} \mathrm{C}$ for further analysis.

Water-Soluble Nitrogen. Ten milliliters of WSE was quantitatively estimated in a digestion bottle by the Kjeldahl determination method. The results were expressed as percentages of total nitrogen in cheese: $\mathrm{pH}$ 4.6-soluble $\mathrm{N}=\mathrm{pH} 4.6$ soluble $\mathrm{N}$ content/total nitrogen content.

Total Free Amino Acids. Total free amino acids (TFAA) was analyzed by using an S433 amino acid analyzer (Sykam GmbH, Eresing, Germany) with an LCA K07/Li cation-exchange column. A mixture of basic, acid, and neutral AA of known concentration was added to glutamic acid and used as the standard.
Amino acids were derivatized postcolumn with ninhydrin reagent and detected by absorbance at 440 (proline and hydroxyproline) or $570 \mathrm{~nm}$ (all other AA).

\section{Analysis of Texture Profile}

Texture profile analysis of cheeses was carried out using Brookfield CT3 Texture Analyzer (AMETEK Brookfield, Middleboro, MA). Samples were removed from the middle of the cheese and cut into $15-\mathrm{mm}$ cubes with a sharp knife, wrapped in plastic to prevent water loss, and maintained at room temperature for $1 \mathrm{~h}$ before testing. The analysis conditions were as follows: TA11/1000 cylinder probe, test speed $0.4 \mathrm{~mm} / \mathrm{s}$, pretest speed $1 \mathrm{~mm} / \mathrm{s}$, compression $50 \%$ of initial height, and 2 compression cycles.

\section{Sensory Evaluation}

Sensory evaluation was performed according to the method of Wang et al. (2015c). Twenty professional panelists (10 women, 10 men, aged 21 to $45 \mathrm{yr}$ ) comprising the laboratory staff and graduate students with over $150 \mathrm{~h}$ of training in cheese evaluation assessed the 3 batches of cheeses at $90 \mathrm{~d}$ of ripening time by texture (1-10 points), appearance (1-10 points), flavor (1-10 points), and overall acceptance (1-10 points).

\section{Antioxidant Activity}

Before the antioxidant assay for 1,1-diphenyl-2-picrylhydrazyl (DPPH), 2,2'-azino-bis(3-ethylbenzothiazoline-6-sulfonic acid) diammonium salt (ABTS), and hydroxyl radical scavenging activity, stored WSE was diluted to a concentration of $50 \mathrm{mg} / \mathrm{mL}$ with deionizeddistilled water.

DPPH Radical Scavenging Activity. Briefly, 200 $\mu \mathrm{L}$ of WSE was mixed with $800 \mu \mathrm{L}$ of $0.2 \mathrm{mM}$ freshly prepared DPPH methanol solution. The mixture was then mixed vigorously and incubated at room temperature in the dark for $40 \mathrm{~min}$. Afterward, the absorbance of the mixture was measured at $517 \mathrm{~nm}$. The DPPH radical scavenging ability was calculated as

Scavenging rate $(\%)=\left[1-\left(\mathrm{A}_{1}-\mathrm{A}_{\mathrm{i}}\right) / \mathrm{A}_{0}\right] \times 100$,

where $A_{1}$ was the absorbance of the sample mixed with $\mathrm{DPPH}, \mathrm{A}_{\mathrm{i}}$ was the absorbance of the sample mixed with methanol, and $A_{0}$ was the absorbance of mixture solution without sample.

ABTS Radical Scavenging Activity. The ABTS ${ }^{\bullet+}$ radical scavenging activity was measured using the method described by Wang et al. (2017). 
Hydroxyl Radical Scavenging Activity. The hydroxyl radical scavenging activity was measured with the Fenton reaction. Briefly, $1 \mathrm{~mL}$ of WSE, $1 \mathrm{~mL}$ of brilliant green $(0.435 \mathrm{mM}), 2 \mathrm{~mL}$ of $\mathrm{FeSO}_{4}(0.5 \mathrm{mM})$, and $1.5 \mathrm{~mL}$ of $\mathrm{H}_{2} \mathrm{O}_{2}(3 \%$, wt/vol $)$ were added to tubes and mixed to initiate the reaction. The tubes were incubated at $37^{\circ} \mathrm{C}$ for $30 \mathrm{~min}$. The absorbance was then measured at $624 \mathrm{~nm}$. The hydroxyl radical scavenging activity was calculated as

$$
\text { Scavenging rate }(\%)=\left[\left(\mathrm{A}_{1}-\mathrm{A}_{\mathrm{i}}\right) /\left(\mathrm{A}_{0}-\mathrm{A}_{\mathrm{i}}\right)\right] \times 100,
$$

where $A_{1}$ was the absorbance of mixture solution with sample, $\mathrm{A}_{i}$ was the absorbance of mixture solution without sample, and $\mathrm{A}_{0}$ was the absorbance of mixture solution without sample and Fenton reaction system.

\section{a-Amylase and a-Glucosidase Inhibitory Activities}

Before the assay, stored WSE was diluted to a concentration of $50 \mathrm{mg} / \mathrm{mL}$ with deionized-distilled water. The $\alpha$-amylase inhibition assay was carried out according to the method described by Al-Dhaheri et al. (2017). Briefly, $100 \mu \mathrm{L}$ of $\alpha$-amylase from human salivary glands (1.0 unit/mL, Sigma-Aldrich, St. Louis, MO) was premixed with $100 \mu \mathrm{L}$ of WSE. After incubation at $37^{\circ} \mathrm{C}$ for $5 \mathrm{~min}, 250 \mu \mathrm{L}$ of $1 \%$ starch was added as a substrate in PBS ( $\mathrm{pH}$ 6.8) to start the reaction. The reaction was performed at $37^{\circ} \mathrm{C}$ for $5 \mathrm{~min}$ and terminated by the addition of $200 \mu \mathrm{L}$ of DNS reagent $(1 \%$ 3,5-dinitrosalicylic acid and $12 \%$ sodium potassium tartrate in $0.4 \mathrm{M} \mathrm{NaOH}$ ). The reaction mixture was heated for $15 \mathrm{~min}$ at $100^{\circ} \mathrm{C}$ and diluted with $2 \mathrm{~mL}$ of distilled water in an ice bath. $\alpha$-Amylase activity was determined by measuring absorbance at $540 \mathrm{~nm}$.

The $\alpha$-glucosidase inhibition assays were carried out according to the method described by Wang et al. (2018b). Briefly, $5 \mu \mathrm{L}$ of $\alpha$-glucosidase solution (1.0 U/ $\mathrm{mL}$ ), $20 \mu \mathrm{L}$ of WSE, and $165 \mu \mathrm{L}$ of sodium phosphate buffer $(0.1 \mathrm{~m} M, \mathrm{pH} 6.8)$ were mixed and incubated in a 96 -well plate at $37^{\circ} \mathrm{C}$ for $10 \mathrm{~min}$. Every $5 \mathrm{~s}, 10 \mu \mathrm{L}$ of $0.95 \mathrm{~m} M$ PNP-Glu (Sigma-Aldrich) solution in $0.1 \mathrm{M}$ PBS ( $\mathrm{pH}$ 6.9) was added to each well and incubated at $37^{\circ} \mathrm{C}$ for $10 \mathrm{~min}$. Thereafter, $100 \mu \mathrm{L}$ of $1 \mathrm{M} \mathrm{Na}_{2} \mathrm{CO}_{3}$ was added into the well to terminate the reaction. Finally, absorbance was determined using a microplate reader (Molecular Devices Co. Ltd., San Jose, CA) at $405 \mathrm{~nm}$ (for $p$-nitrophenol) and compared with that for 4 controls $\left(\mathrm{A}=\right.$ buffer + enzyme + substrate $+\mathrm{Na}_{2} \mathrm{CO}_{3}$; $\mathrm{B}$ $=$ buffer $+\mathrm{Na}_{2} \mathrm{CO}_{3} ; \mathrm{C}=$ buffer + enzyme + sample + substrate $+\mathrm{Na}_{2} \mathrm{CO}_{3}$, and $\mathrm{D}=$ buffer + enzyme + sample $\left.+\mathrm{Na}_{2} \mathrm{CO}_{3}\right)$. The inhibition rate of $\alpha$-glucosidase was calculated as

$$
\text { Inhibition }(\%)=[(\mathrm{A}-\mathrm{C}+\mathrm{D}) /(\mathrm{A}-\mathrm{B})] \times 100 \text {. }
$$

\section{ACE Inhibitory Activity}

Before the assay, stored WSE was diluted to a concentration of $50 \mathrm{mg} / \mathrm{mL}$ with deionized-distilled water. Angiotensin-converting enzyme inhibition was evaluated using the method described by Liu et al. (2018a). Briefly, $10 \mu \mathrm{L}$ of sample solution (containing the sample in $0.1 M$ borate buffer supplemented with $0.3 \mathrm{M} \mathrm{NaCl}$, $\mathrm{pH} 8.3)$ with $45 \mu \mathrm{L}$ of hippuryl-L-histidyl-L-leucine solution [6.5 mM HHL (Sigma-Aldrich) in $0.1 M$ borate buffer supplemented with $0.3 \mathrm{M} \mathrm{NaCl}, \mathrm{pH}$ 8.3] was preincubated at $37^{\circ} \mathrm{C}$ for $5 \mathrm{~min}$, and subsequently incubated with $10 \mu \mathrm{L}$ of ACE $(0.1 \mathrm{U} / \mathrm{mL})$ in $0.1 M$ borate buffer supplemented with $0.3 \mathrm{M} \mathrm{NaCl}(\mathrm{pH} 8.3)$ at $37^{\circ} \mathrm{C}$ for $30 \mathrm{~min}$. The reaction was terminated by adding $85 \mu \mathrm{L}$ of $1 \mathrm{M} \mathrm{HCl}$ to all samples, except for the blank control (before preincubation, $85 \mu \mathrm{L}$ of $1 \mathrm{M} \mathrm{HCl}$ was added). The hippuric acid formed was extracted using $1 \mathrm{~mL}$ of ethyl acetate. Subsequently, $800 \mu \mathrm{L}$ of the ethyl acetate layer was collected and evaporated for $30 \mathrm{~min}$ in a drying oven at $100^{\circ} \mathrm{C}$. The residue was dissolved in $800 \mu \mathrm{L}$ of distilled water and the absorbance of the solution was measured at $228 \mathrm{~nm}$. The ACE inhibitory activity was calculated as

$$
\text { Inhibition }(\%)=[(\mathrm{A}-\mathrm{B}) /(\mathrm{A}-\mathrm{C})] \times 100 \text {, }
$$

where A was the absorbance without the addition of sample solution (buffer solution added instead of sample), B was the absorbance in the presence of $\mathrm{ACE}$ and the sample solution, and $\mathrm{C}$ was the absorbance of the blank ( $\mathrm{HCl}$ was added before the addition of $\mathrm{ACE}$ ).

\section{Antitumor Activity}

Before the assay, stored WSE was diluted to a concentration of $50 \mathrm{mg} / \mathrm{mL}$ with deionized-distilled water. The WSE was then filtered through Macrosep Advance Spin Filter $3 \mathrm{kD}$ (Pall Corporation, Port Washington, NY). Filtrates were assayed for antiproliferative activity on human colon cancer HT-29 according to the method described by Wang et al. (2015a).

\section{Statistical Analysis}

One-way ANOVA was performed with the TukeyKramer post-hoc test to compare the results, and all data were expressed as means \pm standard deviation. Differences at $P<0.05$ were considered statistically significant. 


\section{RESULTS AND DISCUSSION}

\section{Gross Composition, $\mathrm{pH}$ Values, and Water Activity}

The chemical compositions of all cheeses at $0 \mathrm{~d}$ of ripening are summarized in Table 1 . We found no significant differences $(P>0.05)$ in protein, fat-in-dry matter, or water activity levels between the experimental cheeses (B and C) and the control cheese (A). Cheeses B and $\mathrm{C}$ showed slightly and significantly $(P<$ 0.05 ) higher moisture and salt contents than the control cheese, respectively. The higher moisture content in the experimental cheeses might be attributed to the EPS, which increased the water retention capacity of cheese via hydrogen bonding (Lynch et al., 2014). Meanwhile, the increased moisture content might cause the cheese to absorb more salt during the brining period (Ayyash et al., 2018). Previously, addition of EPS-producing strains to low-fat Cheddar cheese was shown to increase moisture and salt contents (Dabour et al., 2006; Ryan et al., 2015). Costa et al. (2010) found that low-fat Cheddar cheese manufactured with the EPS-producing starter Lactococcus lactis ssp. cremoris DPC6532 had higher moisture levels and yields than those of cheese made with a non-EPS-producing variant (Lactococcus lactis ssp. cremoris DPC6533). In addition, we also found no significant differences $(P>0.05)$ in $\mathrm{pH}$ values between the experimental cheeses $(\mathrm{B}$ and $\mathrm{C})$ and the control cheese (A) (Table 1) during the ripening period. The $\mathrm{pH}$ drop might be mainly due to lactose fermentation by LAB in all cheeses.

\section{Microbiological Analysis}

The viabilities of microorganisms in cheese samples during $90 \mathrm{~d}$ of ripening at $4^{\circ} \mathrm{C}$ are shown in Figure 1.
The viable counts of Lc. lactis ST25 (approximately 8.6 $\log \mathrm{cfu} / \mathrm{g}$ at $0 \mathrm{~d}$ ) in all cheese samples showed a significant trend to decrease with increasing ripening time. By $90 \mathrm{~d}$ of ripening, populations of Lc. lactis ST25 decreased to approximately $8.0 \mathrm{log} \mathrm{cfu} / \mathrm{g}$ of cheese, which might be due to death, autolysis, or unfavorable conditions, such as acidic matrix, low water activity, or low storage temperature (O'Donovan et al., 1996; Ganesan et al., 2014). It was interesting to note that the counts of Lc. lactis ST25 in cheeses B and C were both significantly higher $(P<0.05)$ than that of the control cheese at $90 \mathrm{~d}$ of ripening. This might be due to the existence of EPS, which could protect $L c$. lactis ST25 against the unfavorable conditions in cheese; however, the mechanism underlying the protective action by EPS needs further investigation. In contrast, Lb. plantarum JLK0142 showed a slowly increasing trend up to $90 \mathrm{~d}$ of ripening, reaching a final value of $7.99 \mathrm{log} \mathrm{cfu} / \mathrm{g}$ of cheese at the end of ripening. The slow growth of Lb. plantarum JLK0142 might be either due to its enrichment with proteases required to degrade milk protein to produce AA and peptides for its own growth (Solieri et al., 2015) or to the protective effect of EPS in cheese. The results indicated that Lb. plantarum JLK0142 could survive well in low-fat Cheddar cheese during ripening at $4^{\circ} \mathrm{C}$ and that its EPS might be beneficial to the starter culture.

\section{Proteolysis Analysis}

As shown in Figure 2, the levels of water-soluble nitrogen (WSN) and TFAA in all cheeses increased progressively throughout the ripening period, and at 0 d they were relatively low with no significant difference $(P>0.05)$ between the control and the experimental

Table 1. Gross composition (d 0), water activity (d 90), and $\mathrm{pH}$ of low-fat Cheddar cheese (mean $\pm \mathrm{SD} ; \mathrm{n}=3$ )

\begin{tabular}{|c|c|c|c|}
\hline \multirow[b]{2}{*}{ Variable } & \multicolumn{3}{|c|}{ Cheese $^{1}$} \\
\hline & $\mathrm{A}$ & B & $\mathrm{C}$ \\
\hline Moisture (g/100 g) & $36.66 \pm 1.98^{\mathrm{b}}$ & $40.59 \pm 2.08^{\mathrm{ab}}$ & $43.86 \pm 2.31^{\mathrm{a}}$ \\
\hline Protein $(\mathrm{g} / 100 \mathrm{~g})$ & $22.82 \pm 0.30^{\mathrm{a}}$ & $22.08 \pm 0.68^{\mathrm{a}}$ & $22.61 \pm 0.46^{\mathrm{a}}$ \\
\hline Salt $(\mathrm{g} / 100 \mathrm{~g})$ & $1.42 \pm 0.08^{\mathrm{b}}$ & $1.63 \pm 0.04^{\mathrm{ab}}$ & $1.69 \pm 0.12^{\mathrm{a}}$ \\
\hline $\mathrm{FDM}^{2}(\%)$ & $24.67 \pm 0.84^{\mathrm{a}}$ & $24.07 \pm 1.63^{\mathrm{a}}$ & $23.15 \pm 1.36^{\mathrm{a}}$ \\
\hline Water activity (d 90) & $0.93 \pm 0.03^{\mathrm{a}}$ & $0.89 \pm 0.01^{\mathrm{a}}$ & $0.91 \pm 0.01^{\mathrm{a}}$ \\
\hline \multicolumn{4}{|l|}{$\mathrm{pH}$} \\
\hline d 0 & $5.62 \pm 0.10^{\mathrm{A}, \mathrm{a}}$ & $5.66 \pm 0.08^{\mathrm{A}, \mathrm{a}}$ & $5.64 \pm 0.03^{\mathrm{A}, \mathrm{a}}$ \\
\hline d 30 & $5.60 \pm 0.03^{\mathrm{A}, \mathrm{a}}$ & $5.58 \pm 0.12^{\mathrm{AB}, \mathrm{a}}$ & $5.55 \pm 0.15^{\mathrm{A}, \mathrm{a}}$ \\
\hline d 60 & $5.56 \pm 0.04^{\mathrm{A}, \mathrm{a}}$ & $5.51 \pm 0.09^{\mathrm{AB}, \mathrm{a}}$ & $5.49 \pm 0.07^{\mathrm{A}, \mathrm{a}}$ \\
\hline d 90 & $5.53 \pm 0.18^{\mathrm{A}, \mathrm{a}}$ & $5.40 \pm 0.05^{\mathrm{B}, \mathrm{a}}$ & $5.42 \pm 0.06^{\text {A.a }}$ \\
\hline
\end{tabular}

${ }_{\mathrm{A}, \mathrm{B}}$ Means for $\mathrm{pH}$ in the same column followed by different superscripts are significantly different $(P<0.05)$.

${ }^{\mathrm{a}, \mathrm{b}}$ Means in the same row followed by different superscripts are significantly different $(P<0.05)$.

${ }^{1}$ Cheese: $\mathrm{A}=$ control cheese; $\mathrm{B}=$ cheese made with addition of purified exopolysaccharide ingredient; $\mathrm{C}=$ cheese made with exopolysaccharide-producing Lactobacillus plantarum JLK0142 as an adjunct culture.

${ }^{2} \mathrm{FDM}=$ fat-in-dry matter. 
cheeses. However, after $90 \mathrm{~d}$ of ripening, WSN and TFFA in all cheeses increased significantly $(P<0.05)$, and the cheeses made with $L$ b. plantarum JLK0142 had similar levels of WSN and TFFA to those produced with EPS, but they all had significantly higher $(P<0.05)$ levels than the control cheeses. The WSN and TFAA were considered to represent indicator variables for proteolysis that affected cheese quality parameters (especially texture, taste, and flavor) and bioactivities (Ayyash et al., 2018). McSweeney (2004) reported that the nitrogen fractions soluble at $\mathrm{pH} 4.6$ or water increased during the ripening period because of the breakdown of casein into peptides and AA by the action of residual chymosin, plasmin, and bacterial cultures. In the present study, the higher WSN and TFAA in the experimental cheeses might be due to accelerated primary proteolysis, along with high proteolytic activities of the EPS-producing Lb. plantarum JLK0142. Our results were consistent with those of Madkor et al. (2000), who found that the major role of adjunct lactobacilli in milled curd Cheddar cheese was to increase free AA levels. However, no differences in primary proteolysis were observed in Cheddar cheeses made with and without adjunct EPS- producing Lactobacillus reuteri cc 2 cultures after 3 mo of ripening (Lynch et al., 2014), suggesting that the Lactobacillus cultures did not contribute to primary proteolysis. These microorganisms were known to be weakly proteolytic, and therefore did not contribute considerably to the hydrolysis of casein during cheese ripening (Sousa et al., 2001).

In our study, the significantly higher levels of primary proteolysis in the experimental cheese indicated that Lb. plantarum JLK0142 could greatly alter the peptide profiles of the cheese. This might represent a promising feature of this strain in cheese production based on the possible presence of bioactive peptides in cheese. Further studies on the peptide profile and mechanism of the peptide formation and action during the cheese ripening would be of interest to elucidate the roles of the peptides in cheese flavor, texture, and functional properties. A few reports are available demonstrating the effect of adjunct EPS-producing $L b$. plantarum on peptide profiles, including formation of bioactive peptides in low-fat Cheddar cheese. Furthermore, the highest TFAA found in the cheese with $L b$. plantarum JLK0142 as an adjunct indicated the ability of this

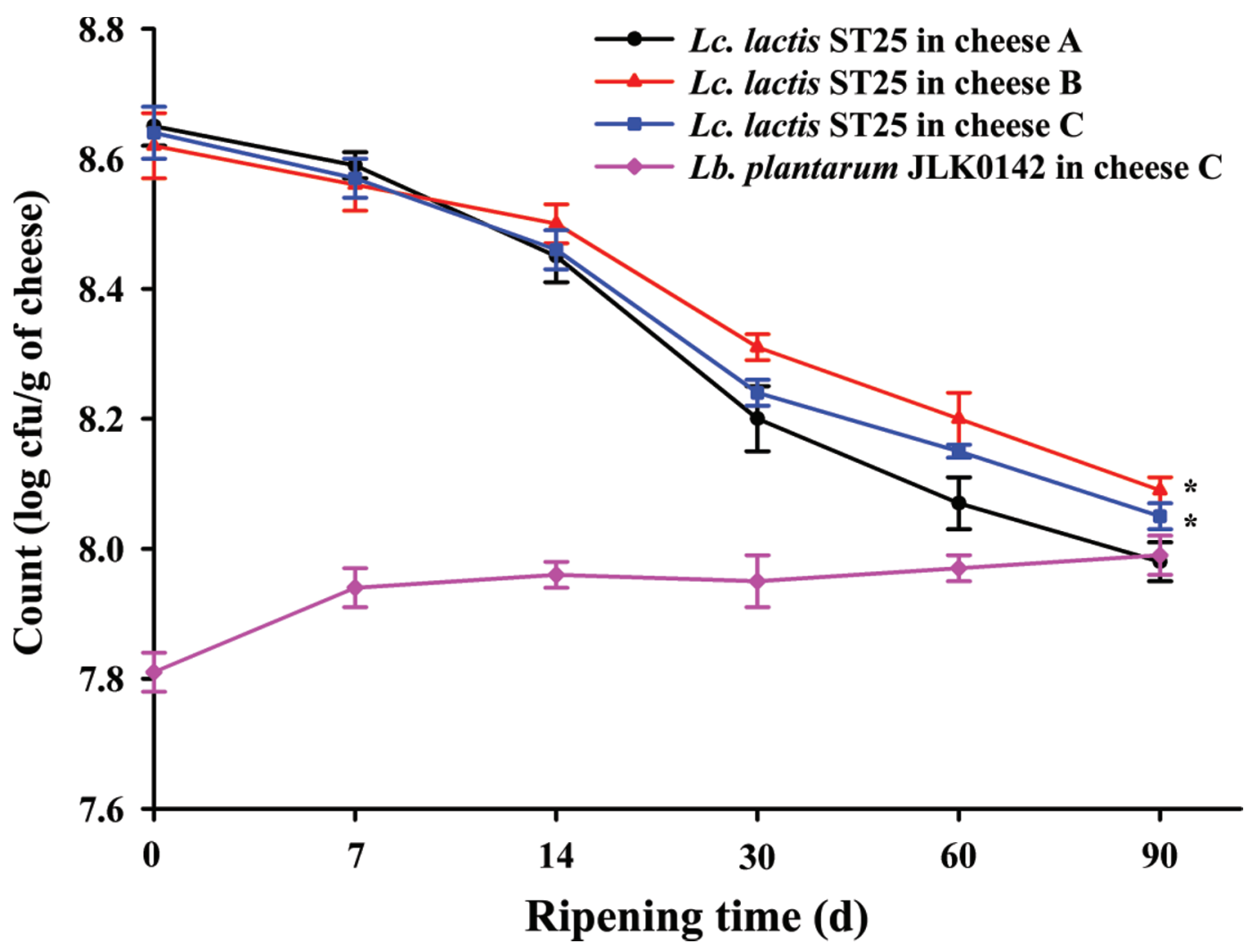

Figure 1. Viability of Lactococcus lactis ST25 and Lactobacillus plantarum JLK0142 in low-fat Cheddar cheese during $90 \mathrm{~d}$ of ripening at $4^{\circ} \mathrm{C} . \mathrm{A}=$ control cheese; $\mathrm{B}=$ experimental cheese made with the addition of purified exopolysaccharide ingredient; $\mathrm{C}=$ experimental cheese made with the addition of exopolysaccharide-producing Lb. plantarum JLK0142. ${ }^{*} P<0.05$ vs. control. Values shown are mean $\pm \mathrm{SD}(\mathrm{n}=3)$. 


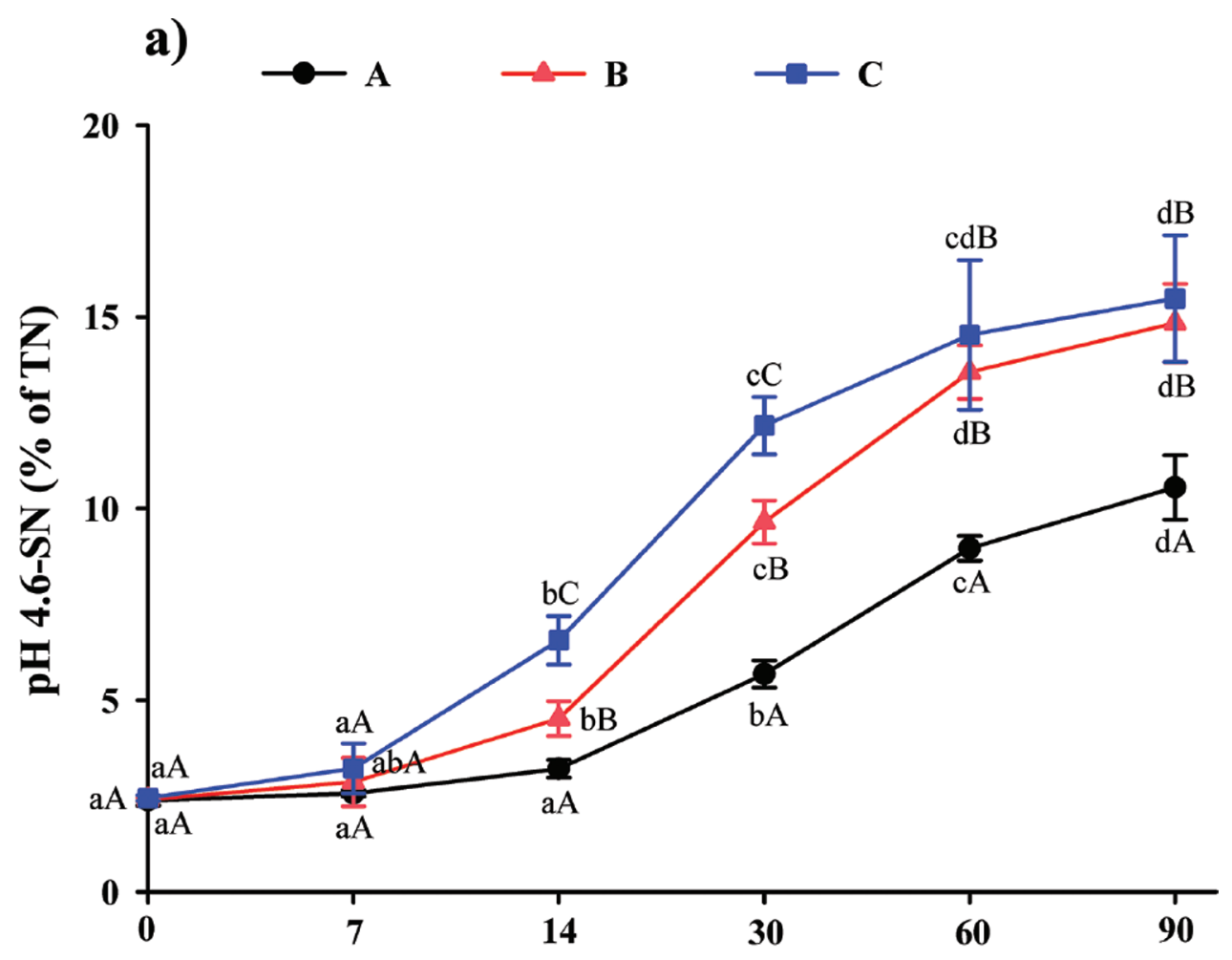

\section{b)}

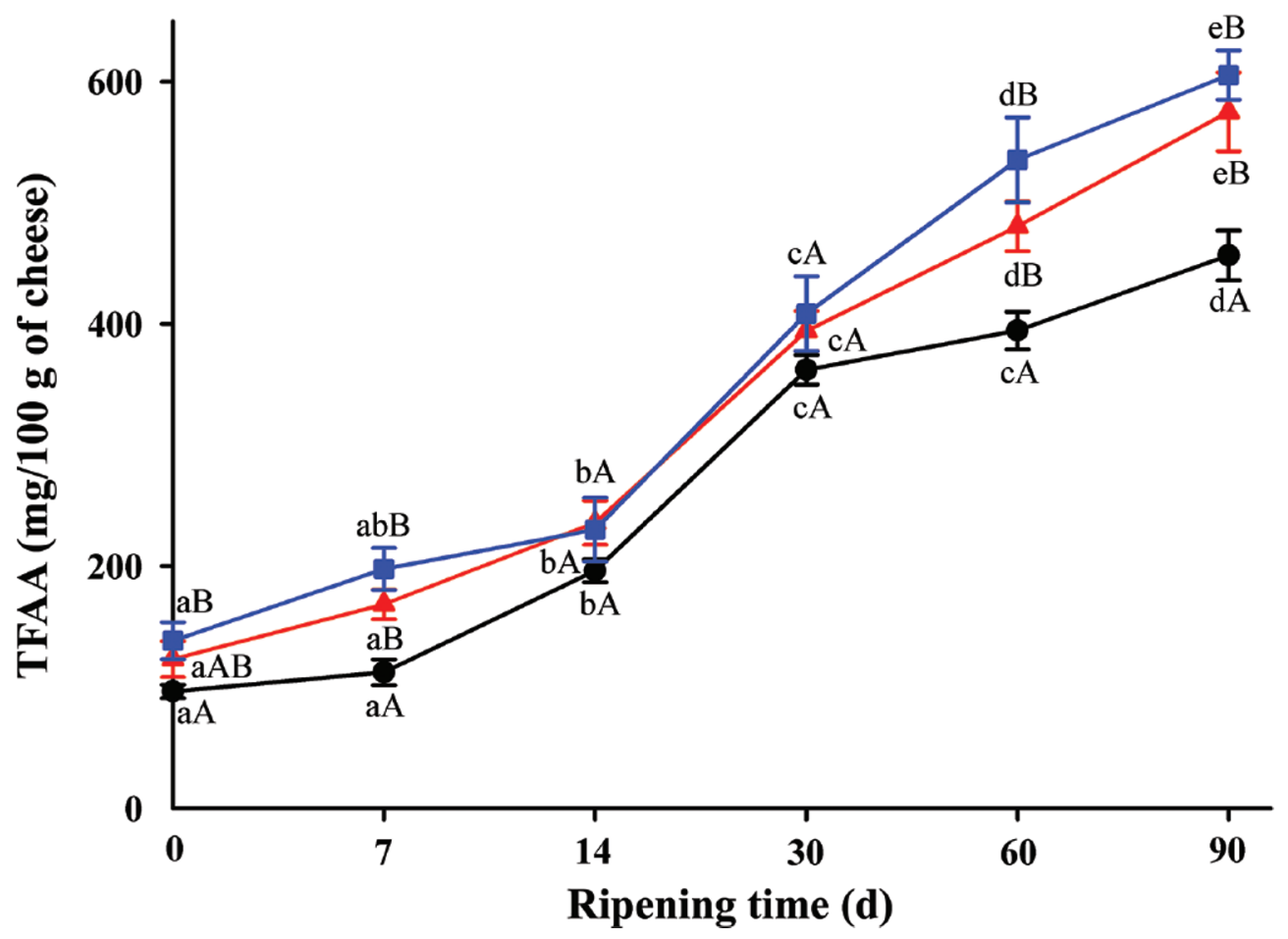

Figure 2. (A) Nitrogen soluble in water at $\mathrm{pH} 4.6$ (pH 4.6-SN) as a percent of total N (TN) and (B) total free amino acids (TFAA) of low-fat Cheddar cheese during $90 \mathrm{~d}$ of ripening at $4^{\circ} \mathrm{C} . \mathrm{A}=$ control cheese; $\mathrm{B}=$ experimental cheese made with the addition of purified exopolysaccharide ingredient; $\mathrm{C}=$ experimental cheese made with the addition of exopolysaccharide-producing Lactobacillus plantarum JLK0142. Means among different ripening times with different lowercase letters $(\mathrm{a}-\mathrm{e})$ are significantly different $(P<0.05)$; means among different cheeses with uppercase letters $(\mathrm{A}-\mathrm{C})$ are significantly different $(P<0.05)$. Values shown are mean $\pm \mathrm{SD}(\mathrm{n}=3)$. 
Table 2. Texture profile analysis of low-fat Cheddar cheese during $90 \mathrm{~d}$ of ripening at $4^{\circ} \mathrm{C}($ mean $\pm \mathrm{SD} ; \mathrm{n}=3)$

\begin{tabular}{llccc}
\hline & & \multicolumn{3}{c}{ Cheese $^{1}$} \\
\cline { 3 - 5 } Variable & $\begin{array}{c}\text { Ripening } \\
\text { time }(\mathrm{d})\end{array}$ & $\mathrm{A}$ & $\mathrm{B}$ & $\mathrm{C}$ \\
\cline { 3 - 5 } Hardness $(\mathrm{kg})$ & 0 & $4.89 \pm 0.56^{\mathrm{a}, \mathrm{A}}$ & $3.56 \pm 0.38^{\mathrm{a}, \mathrm{B}}$ & $3.12 \pm 0.37^{\mathrm{a}, \mathrm{B}}$ \\
& 30 & $4.15 \pm 0.74^{\mathrm{a}, \mathrm{A}}$ & $3.02 \pm 0.12^{\mathrm{ab}, \mathrm{B}}$ & $2.84 \pm 0.20^{\mathrm{a}, \mathrm{B}}$ \\
& 60 & $3.68 \pm 0.22^{\mathrm{ab}, \mathrm{A}}$ & $2.68 \pm 0.15^{\mathrm{bc}, \mathrm{B}}$ & $1.89 \pm 0.15^{\mathrm{b}, \mathrm{C}}$ \\
& 90 & $2.67 \pm 0.38^{\mathrm{b}, \mathrm{A}}$ & $2.17 \pm 0.09^{\mathrm{c}, \mathrm{B}}$ & $1.53 \pm 0.13^{\mathrm{b}, \mathrm{B}}$ \\
Cohesiveness & 0 & $0.88 \pm 0.01^{\mathrm{a}, \mathrm{A}}$ & $0.79 \pm 0.03^{\mathrm{a}, \mathrm{B}}$ & $0.76 \pm 0.03^{\mathrm{a}, \mathrm{B}}$ \\
& 30 & $0.82 \pm 0.02^{\mathrm{b}, \mathrm{A}}$ & $0.77 \pm 0.01^{\mathrm{ab}, \mathrm{AB}}$ & $0.73 \pm 0.04^{\mathrm{ab}, \mathrm{B}}$ \\
& 60 & $0.79 \pm 0.02^{\mathrm{bc}, \mathrm{A}}$ & $0.72 \pm 0.02^{\mathrm{bc}, \mathrm{B}}$ & $0.72 \pm 0.01^{\mathrm{ab}, \mathrm{B}}$ \\
& 90 & $0.75 \pm 0.01^{\mathrm{c}, \mathrm{A}}$ & $0.70 \pm 0.02^{\mathrm{c}, \mathrm{B}}$ & $0.68 \pm 0.01^{\mathrm{b}, \mathrm{B}}$ \\
Springiness $(\mathrm{mm})$ & 0 & $0.84 \pm 0.03^{\mathrm{a}, \mathrm{B}}$ & $0.88 \pm 0.01^{\mathrm{a}, \mathrm{AB}}$ & $0.90 \pm 0.01^{\mathrm{a}, \mathrm{A}}$ \\
& 30 & $0.82 \pm 0.02^{\mathrm{ab}, \mathrm{A}}$ & $0.86 \pm 0.01^{\mathrm{a}, \mathrm{A}}$ & $0.85 \pm 0.03^{\mathrm{b}, \mathrm{A}}$ \\
& 60 & $0.77 \pm 0.02^{\mathrm{bc}, \mathrm{B}}$ & $0.82 \pm 0.02^{\mathrm{b}, \mathrm{A}}$ & $0.83 \pm 0.01^{\mathrm{bc}, \mathrm{A}}$ \\
& 90 & $0.74 \pm 0.01^{\mathrm{c}, \mathrm{C}}$ & $0.77 \pm 0.01^{\mathrm{c}, \mathrm{B}}$ & $0.80 \pm 0.01^{\mathrm{c}, \mathrm{A}}$ \\
& 0 & $1.78 \pm 0.21^{\mathrm{a}, \mathrm{A}}$ & $1.52 \pm 0.30^{\mathrm{a}, \mathrm{A}}$ & $1.46 \pm 0.13^{\mathrm{a}, \mathrm{A}}$ \\
& 30 & $1.54 \pm 0.17^{\mathrm{a}, \mathrm{A}}$ & $1.38 \pm 0.15^{\mathrm{ab}, \mathrm{A}}$ & $1.29 \pm 0.20^{\mathrm{ab}, \mathrm{A}}$ \\
& 60 & $1.06 \pm 0.09^{\mathrm{b}, \mathrm{A}}$ & $0.94 \pm 0.05^{\mathrm{bc}, \mathrm{A}}$ & $1.03 \pm 0.03^{\mathrm{bc}, \mathrm{A}}$ \\
& 90 & $0.72 \pm 0.02^{\mathrm{b}, \mathrm{B}}$ & $0.85 \pm 0.01^{\mathrm{c}, \mathrm{A}}$ & $0.76 \pm 0.02^{\mathrm{c}, \mathrm{B}}$ \\
\hline
\end{tabular}

${ }^{\mathrm{a}-\mathrm{c}}$ Means in the same column and within a variable followed by different superscripts are significantly different $(P<0.05)$.

${ }^{\mathrm{A}-\mathrm{C}}$ Means in the same row followed by different superscripts are significantly different $(P<0.05)$.

${ }^{1}$ Cheese: $\mathrm{A}=$ control cheese; $\mathrm{B}=$ cheese made with addition of purified exopolysaccharide ingredient; $\mathrm{C}=$ cheese made with exopolysaccharide-producing Lactobacillus plantarum JLK0142 as an adjunct culture.

strain to promote secondary proteolysis and its potential contribution to cheese flavor. Free AA levels were also observed to be higher in cheeses containing adjunct lactobacilli (Al-Dhaheri et al., 2017). The use of EPSproducing Weissella cibaria MG1 as adjuncts to manufacture Cheddar cheese resulted in significant increase in formation of free AA after $90 \mathrm{~d}$ of ripening (Lynch et al., 2014). The proteolytic activity of adjuncts is often considered to be significant and sometimes desired, as free AA can serve as precursors to flavor and aroma compounds in cheese (Bintsis and Robinson, 2004).

\section{Texture Profile Analysis}

Table 2 shows the changes in hardness, cohesiveness, springiness, and chewiness of the low-fat Cheddar cheese during $90 \mathrm{~d}$ of ripening at $4^{\circ} \mathrm{C}$. Four texture parameters significantly decreased $(P<0.05)$ throughout the ripening period. The hardness and cohesiveness of the cheeses produced with Lb. plantarum JLK0142 were close to those of the cheeses produced with EPS and both significantly lower $(P<0.05)$ than those of the control cheese at 0 and $90 \mathrm{~d}$ of ripening. The lower hardness in the experimental cheeses might be attributed to their higher moisture content compared with the control cheese (Table 1), and the lower cohesiveness might be due to breakage of internal bonds caused by their higher primary proteolysis activities (Figure 2). Our results were similar to the findings of Dabour et al. (2006), who found that reduced-fat Cheddar cheeses with ropy EPS-producing culture had lower hardness and cohesiveness compared with non-EPS-producing cultures. In the present study, springiness of the control cheese was significantly lower $(P<0.05)$ than the experimental cheeses at the end of ripening, which might be attributed to the lower moisture content of the control cheese (Table 1). Moreover, the trend toward a change in cheese chewiness during ripening was similar to that of hardness. Cheese hardness was positively correlated with chewiness (Wang et al., 2015c); hence, the control cheese with higher hardness was significantly chewier $(P<0.05)$ than the experimental cheeses at the end of the ripening period.

\section{Sensory Analysis}

The average scores for sensory evaluation of the low-fat Cheddar cheeses at $90 \mathrm{~d}$ of ripening are shown in Table 3. We found no differences between the experimental and the control cheeses in terms of appearance and overall acceptability; however, cheese $\mathrm{C}$ had a significantly higher $(P<0.05)$ texture score than cheeses A or B. Moreover, cheeses B and C showed similar flavor scores, both of which were significantly higher $(P<0.05)$ than that of cheese A. Many different factors, including degree of proteolysis, concentration of free AA and fat, milk source, type of starter culture, and technological conditions, could influence the sensory characteristics of cheese (Ahmed et al., 2005; Hou et al., 2014). Milesi et al. (2009) reported that the sensory characteristics of soft and semi-hard cheeses were improved by using Lactobacillus casei I90 and $L b$. 
Table 3. Sensory analysis (score) of low-fat Cheddar cheese after ripening for $90 \mathrm{~d}$ (mean $\pm \mathrm{SD} ; \mathrm{n}=3$ )

\begin{tabular}{lcccc}
\hline & \multicolumn{3}{c}{ Sensory attribute } \\
\cline { 2 - 5 } Cheese $^{1}$ & Texture & Appearance & Flavor & Overall acceptance \\
\hline $\mathrm{A}$ & $6.3 \pm 0.7^{\mathrm{a}}$ & $7.1 \pm 0.9^{\mathrm{a}}$ & $6.8 \pm 0.5^{\mathrm{a}}$ & $7.4 \pm 0.2^{\mathrm{a}}$ \\
$\mathrm{B}$ & $6.5 \pm 0.2^{\mathrm{a}}$ & $7.5 \pm 0.7^{\mathrm{a}}$ & $7.6 \pm 0.3^{\mathrm{b}}$ & $7.2 \pm 0.5^{\mathrm{a}}$ \\
$\mathrm{C}$ & $7.2 \pm 0.6^{\mathrm{b}}$ & $7.3 \pm 0.5^{\mathrm{a}}$ & $7.5 \pm 0.4^{\mathrm{b}}$ & $7.7 \pm 0.3^{\mathrm{a}}$ \\
\hline
\end{tabular}

${ }^{\mathrm{a}, \mathrm{b}}$ Means in the same column followed by different superscripts are significantly different $(P<0.05)$.

${ }^{1}$ Cheese: $\mathrm{A}=$ control cheese; $\mathrm{B}=$ cheese made with addition of purified exopolysaccharide ingredient; $\mathrm{C}=$ cheese made with exopolysaccharide-producing Lactobacillus plantarum JLK0142 as an adjunct culture.

plantarum I91, which possessed peptidolytic activity as adjunct cultures. The supplementation of cheeses with probiotic bacteria could promote proteolysis and break the initial network structure of casein to increase the TFAA content and the formation of flavor and aromatic compounds, as well as soften the cheese (Cruz et al., 2009). We therefore concluded that the elevated texture and flavor scores of cheeses made with $L b$. plantarum JLK0142 might be because of higher moisture content (Table 1) and proteolysis activity (Figure 2).

\section{Antioxidant Activity}

The antioxidant activity of the low-fat Cheddar cheese was determined during $90 \mathrm{~d}$ of ripening at $4^{\circ} \mathrm{C}$ by analyzing its scavenging ability on DPPH, hydroxyl, and ABTS radicals. As shown in Figure 3, all the scavenging rates increased significantly $(P<0.05)$ with prolonged storage. In particular, the scavenging rates of DPPH, hydroxyl, and ABTS radicals in the control cheese A increased from $30.63 \pm 0.95,15.62 \pm 3.56$, and $26.54 \pm 3.25 \%$ to $38.17 \pm 2.36,32.45 \pm 5.68$, and 49.23 $\pm 3.87 \%$, respectively. The corresponding rates in experimental cheese B increased from $35.21 \pm 2.72,16.85$ \pm 4.12 , and $40.15 \pm 3.21 \%$ to $48.62 \pm 1.65,38.62 \pm$ 6.85 , and $68.34 \pm 6.13 \%$, respectively; in experimental cheese $\mathrm{C}$ from $35.62 \pm 3.65,15.96 \pm 5.62$, and $38.46 \pm$ $4.38 \%$ to $45.88 \pm 2.56,36.63 \pm 4.94$, and $67.56 \pm 5.69 \%$, respectively. Scavenging activities of the experimental cheeses were significantly higher $(P<0.05)$ than those of the control cheeses. Cheeses made with Lb. plantarum JLK0142 exhibited comparable antioxidant activity to those made with EPS. In addition, after $90 \mathrm{~d}$ of ripening storage, the scavenging rates in the experimental cheeses increased by $>65 \%$ for ABTS radicals (Figure $3 \mathrm{C}$ ), $>45 \%$ for DPPH radicals (Figure $3 \mathrm{~A}$ ), and $>35 \%$ for hydroxyl radicals (Figure 3B). The difference in the scavenging rates for these 3 radicals $(\mathrm{ABTS}>\mathrm{DPPH}>$ hydroxyl) might be due to the nature of the antioxidant test (Al-Dhaheri et al., 2017). During cheese ripening, the increased proteolysis might result in formation of more bioactive peptides, including antioxidant peptides that were released from their inactive state in the parent protein structure, thus increasing the antioxidant activity of the experimental cheeses (B and C). On the other hand, the increased antioxidant activity might also be attributed to the gradual increase of bioactive EPS produced by Lb. plantarum JLK0142 with prolonged storage. Previously the EPS produced by $L b$. plantarum strains was shown to possess desirable antioxidant activities (Dilna et al., 2015; Wang et al., 2017). The DPPH, hydroxyl, and ABTS radical scavenging abilities of cheese were found to correlate with the degree of proteolysis (Liu et al., 2018b). Therefore, incorporation of EPS-producing probiotics in foods, especially fermented dairy products, may be a promising technological strategy to supply dietary antioxidants. However, further study should be performed to clarify the relevant antioxidant mechanism.

\section{a-Amylase and a-Glucosidase Inhibitory Activities}

The $\alpha$-amylase and $\alpha$-glucosidase inhibition results for low-fat Cheddar cheese during $90 \mathrm{~d}$ of ripening at $4^{\circ} \mathrm{C}$ are illustrated in Figure $4 \mathrm{~A}$ and $4 \mathrm{~B}$, respectively. The $\alpha$-amylase inhibition rates of all cheese samples ranged from $>21 \%$ at 0 d to $\sim 45 \%$ at $90 \mathrm{~d}$ of storage, representing a significant $(P<0.05)$ increase with prolonged storage. The experimental cheeses (B and C) showed higher $(P<0.05) \alpha$-amylase inhibition rates than the control cheese (A) after $30 \mathrm{~d}$ of storage. The highest rate was observed in the cheese made with Lb. plantarum JLK0142 (45.63 $\pm 2.05 \%)$, followed by the cheese made with the EPS $(41.03 \pm 1.35 \%)$ and the control cheese $(33.62 \pm 1.82 \%)$ at $90 \mathrm{~d}$ of storage. Addition of Lb. plantarum JLK0142 could increase proteolysis of cheese (Figure 2), which might result in formation of more antidiabetic peptides. These bioactive peptides could be released from the parent protein structure, thus increasing antidiabetic activity of cheese (Abadía-García et al., 2013). Similar to the trends in $\alpha$-amylase and $\alpha$-glucosidase inhibitory activities of all cheese samples also significantly $(P<0.05)$ increased with prolonged storage. The $\alpha$-glucosidase inhibition 

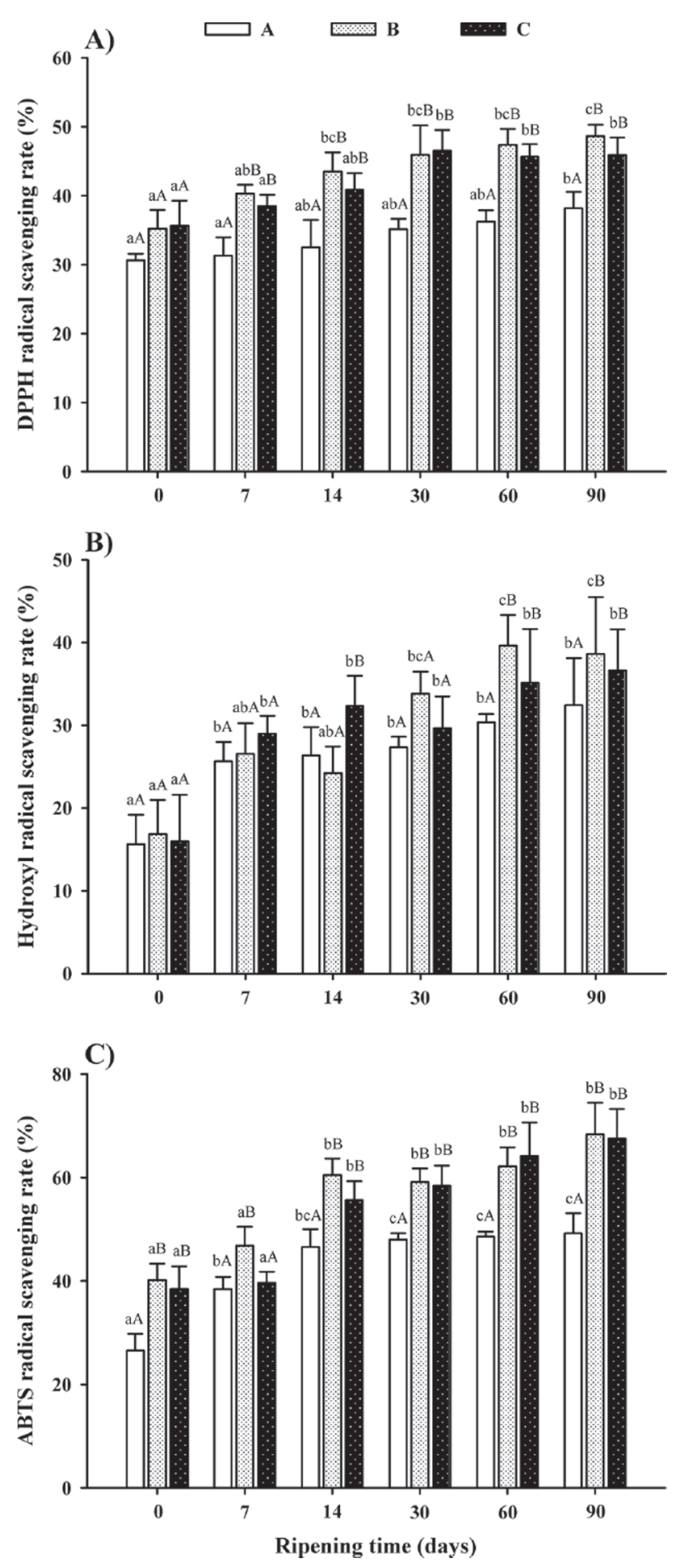

Figure 3. Scavenging activities on the 1,1-diphenyl-2-picrylhydrazyl (DPPH; A), hydroxyl (B), and 2,2'-azino-bis(3-ethylbenzothiazoline-6-sulfonic acid) diammonium salt (ABTS) radicals (C) of low-fat Cheddar cheese during $90 \mathrm{~d}$ of ripening at $4^{\circ} \mathrm{C} . \mathrm{A}=$ control cheese; $\mathrm{B}$ = experimental cheese made with the addition of purified exopolysaccharide ingredient; $\mathrm{C}=$ experimental cheese made with the addition of exopolysaccharide-producing Lactobacillus plantarum JLK0142. Means among different ripening time with different lowercase letters $(\mathrm{a}-\mathrm{c})$ are significantly different $(P<0.05)$; means among different cheeses with uppercase letters $(\mathrm{A}, \mathrm{B})$ are significantly different $(P<$ $0.05)$. Values shown are mean $\pm \operatorname{SD}(\mathrm{n}=3)$.

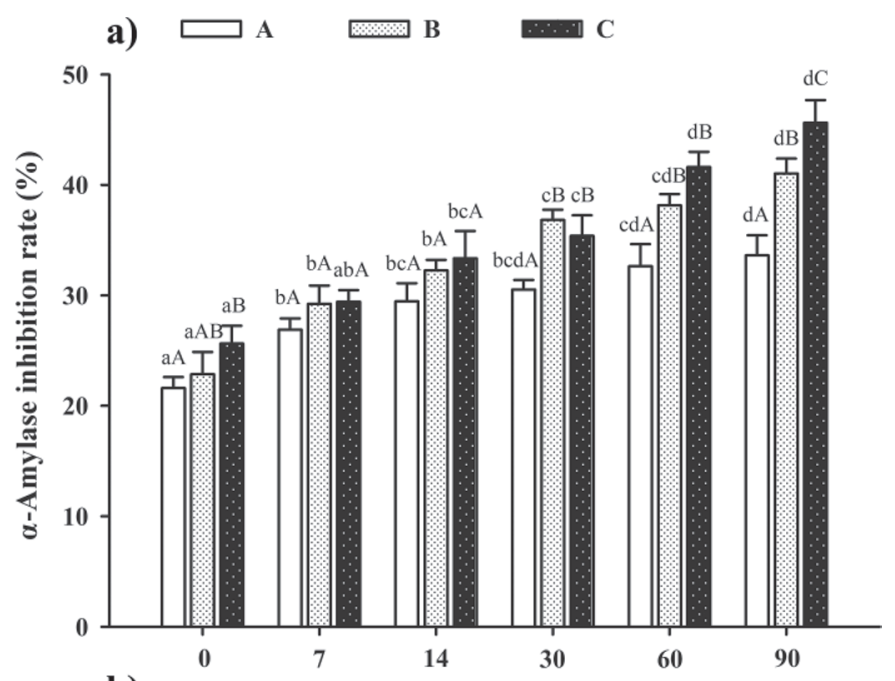

b)

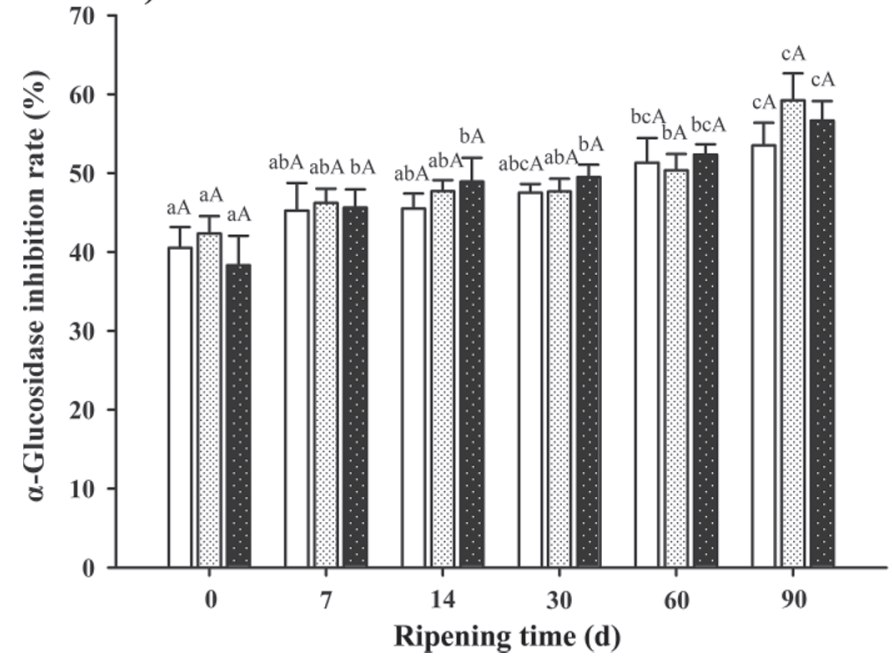

Figure 4. Inhibitory activities against $\alpha$-amylase (A) and $\alpha$-glucosidase (B) of low-fat Cheddar cheese during $90 \mathrm{~d}$ of ripening at $4^{\circ} \mathrm{C}$. $\mathrm{A}=$ control cheese; $\mathrm{B}=$ experimental cheese made with the addition of purified exopolysaccharide ingredient; $\mathrm{C}=$ experimental cheese made with the addition of exopolysaccharide-producing Lactobacillus plantarum JLK0142. Means among different ripening times with different lowercase letters $(\mathrm{a}-\mathrm{d})$ are significantly different $(P<0.05)$; means among different cheeses with uppercase letters $(\mathrm{A}-\mathrm{C})$ are significantly different $(P<0.05)$. Values shown are mean $\pm \mathrm{SD}(\mathrm{n}=3)$.

rates ranged from $>40 \%$ at $0 \mathrm{~d}$ to $\sim 56 \%$ at $90 \mathrm{~d}$ of storage. Although the $\alpha$-glucosidase inhibition rates of the experimental cheeses were higher than that of the control cheese after $90 \mathrm{~d}$ storage, the difference was not significant $(P>0.05)$.

The inhibition of $\alpha$-amylase and $\alpha$-glucosidase enzymes was considered as an effective approach to control diabetes by diminishing carbohydrate hydrolysis (Ye et al., 2010). Inhibition of both $\alpha$-amylase and $\alpha$-glucosidase enzymes might be attributable to bioactive peptides, particularly smaller ones produced as a result of proteolytic enzymes secreted by cheese 
cultures (Cruz et al., 2009). As indicated in the proteolysis assessment (WSN and TFAA assays) in our study, more bioactive peptides might be formed in the experimental cheeses that correlated with increased $\alpha$-amylase and $\alpha$-glucosidase inhibition rates. In addition, the bioactive EPS produced by $L b$. plantarum might also contribute to the inhibition of $\alpha$-amylase and $\alpha$-glucosidase enzymes (Sasikumar et al., 2017). Therefore, we assumed that the higher $\alpha$-amylase- and $\alpha$-glucosidase-inhibitory activities of the experimental cheeses might be attributed to the bioactive peptides and the EPS released by Lb. plantarum JLK0142. However, the mechanisms of $\alpha$-amylase and $\alpha$-glucosidase inhibition by EPS require further investigation.

\section{ACE Inhibitory Activity}

As shown in in Figure 5, after $90 \mathrm{~d}$ of ripening, the ACE inhibitory activities of all cheese samples increased significantly $(P<0.05)$. The cheese made with $L b$. plantarum JLK0142 showed the highest ACE inhibitory rate $(69.47 \% \pm 4.68 \%)$, followed by the cheese made with EPS $(64.22 \% \pm 3.69 \%)$ and the control cheese $(50.64 \%$ $\pm 3.53 \%$ ), suggesting that addition of $L b$. plantarum JLK0142 might be conducive to generation of ACE inhibitory peptides. Inhibition of ACE activity was considered as an in vitro indicator of the antihypertensive activities of many fermented milk products (Al-Dhaheri

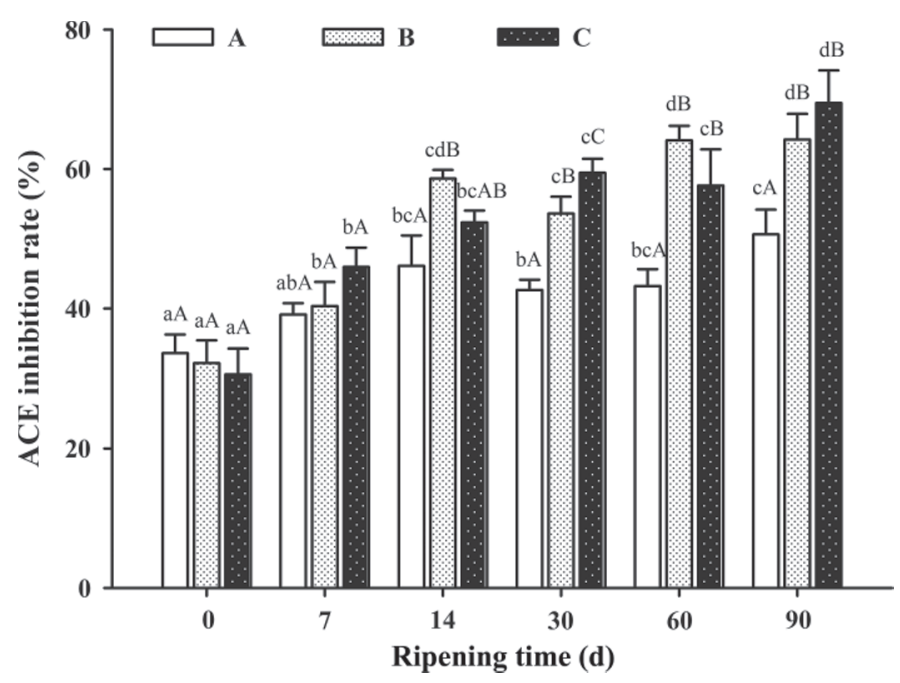

Figure 5. Angiotensin-converting enzyme (ACE) inhibitory activities of low-fat Cheddar cheese during $90 \mathrm{~d}$ of ripening at $4^{\circ} \mathrm{C}$. $\mathrm{A}=$ control cheese; $\mathrm{B}=$ experimental cheese made with the addition of purified exopolysaccharide ingredient; $\mathrm{C}=$ experimental cheese made with the addition of exopolysaccharide-producing Lactobacillus plantarum JLK0142. Means among different ripening times with different lowercase letters $(\mathrm{a}-\mathrm{d})$ are significantly different $(P<0.05)$; means among different cheeses with uppercase letters $(\mathrm{A}-\mathrm{C})$ are significantly different $(P<0.05)$. Values shown are mean $\pm \mathrm{SD}(\mathrm{n}=3)$. et al., 2017). Studies on ACE-inhibiting peptides and the ACE inhibitory activities of different cheese varieties have already been conducted (Bernabucci et al., 2014; Stuknytė et al., 2015). However, to date, no study has been performed on the ACE inhibitory activity of low-fat Cheddar cheese. In the present study, the higher ACE inhibitory activities of the experimental cheeses might be attributed to the combined effects of the EPS and $L$ b. plantarum JLK0142. These results were consistent with that of Al-Dhaheri et al. (2017), who found that EPS-producing cultures were capable of enhancing the ACE inhibitory activity of low-fat Akawi cheese compared with non-EPS-producing cultures. According to Ayyash et al. (2012), the ACE inhibitory activity of fermented dairy products might be primarily attributed to the biologically active peptides produced by the action of proteinases and peptidases from adjunct cultures during fermentation. Donkor et al. (2007) reported that some probiotic strains possessed proteolytic activity in milk-based media and could produce potent $\mathrm{ACE}$ inhibitory peptides during fermentation of milk. Therefore, we postulated that $L b$. plantarum JLK0142 and its EPS in low-fat Cheddar cheeses may have contributed to their ACE inhibitory activities.

\section{Antitumor Activity}

The antitumor activity of low-fat Cheddar cheese was determined during a 90-d ripening period at $4^{\circ} \mathrm{C}$. As shown in Figure 6, all the cheese samples exhibited inhibitory activities against HT-29 cells in a ripening time-dependent manner. The experimental cheeses (B and $\mathrm{C}$ ) displayed higher inhibition rates than those of the control cheese throughout the ripening period. At $90 \mathrm{~d}$ of ripening, the highest inhibition rate $(34.12 \pm$ $3.52 \%$ ) was observed for the cheese made with EPS, followed by the cheese made with $L b$. plantarum JLK0142 (33.25 $\pm 2.36 \%)$ and the control cheese $(28.15$ $\pm 1.61 \%)$. Fermented dairy products were reported to possess antitumor activities due to bioactive milk peptides or EPS produced by cultures (Al-Dhaheri et al., 2017). Wang et al. (2015a) reported that the EPS from $L b$. plantarum YW32 showed strong in vitro inhibitory activity against colon cancer HT-29 cells. The EPS from Lb. plantarum WLPL04 and Lb. plantarum 70810 also exhibited antiproliferative effects on HT-29 cells (Wang et al., 2014; Liu et al., 2017). Therefore, the EPS produced by Lb. plantarum JLK0142 in the low-fat Cheddar cheese might contribute to the antitumor activity. As Lb. plantarum JLK0142 also affected significantly the primary proteolysis of cheese (Figure 2 ), the resulting bioactive peptides formed during the $90 \mathrm{~d}$ of ripening might cause the increased bioactivities such as antitumor, antioxidant, ACE inhibition, and 


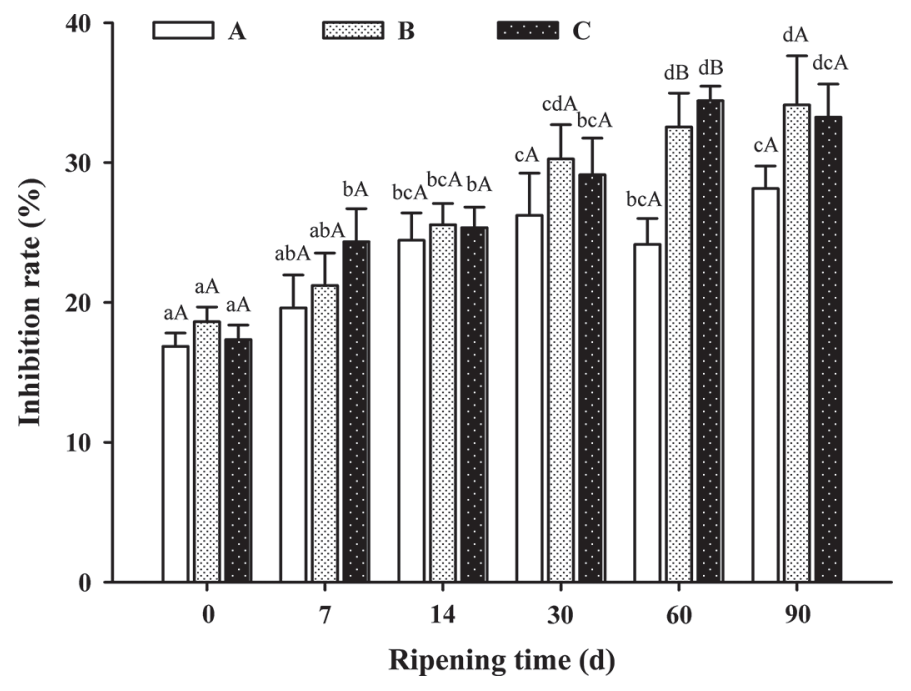

Figure 6. Inhibitory activities against human colon cancer HT-29 cells of low-fat Cheddar cheese during $90 \mathrm{~d}$ of ripening at $4^{\circ} \mathrm{C}$. $\mathrm{A}=$ control cheese; $\mathrm{B}=$ experimental cheese made with the addition of purified exopolysaccharide ingredient; $\mathrm{C}=$ experimental cheese made with the addition of exopolysaccharide-producing Lactobacillus plantarum JLK0142. Means among different ripening times with different lowercase letters $(\mathrm{a}-\mathrm{d})$ are significantly different $(P<0.05)$; means among different cheeses with uppercase letters (A,B) are significantly different $(P<0.05)$. Values shown are mean $\pm \mathrm{SD}(\mathrm{n}=3)$.

$\alpha$-amylase and $\alpha$-glucosidase inhibition, as described above. Previously, 3-mo-old probiotic Cheddar cheese produced by $L b$. plantarum K25 as an adjunct culture was shown to reduce serum cholesterol levels in mice fed a high-fat diet (Zhang et al., 2013b). The low-fat Cheddar cheese with beneficial health properties was made with probiotic Bifidobacterium animalis ssp. lactis, Lactobacillus rhamnosus, Lactobacillus paracasei/ casei, and $L b$. plantarum by ripening at $4^{\circ} \mathrm{C}$ for $90 \mathrm{~d}$ (Demers-Mathieu et al., 2016). Although significant changes in the physicochemical, microbiological, and functional properties of cheese might take place in the first $3 \mathrm{mo}$ of ripening (Zhang et al., 2013b; Lynch et al., 2014; Wang et al., 2018c), it would be of interest to study changes of different bioactivities and the related mechanisms in the low-fat Cheddar cheese upon longer storage than 3 mo.

\section{CONCLUSIONS}

The results of our study confirmed the improvement of the ripening characteristics and in vitro health-promoting benefits of low-fat Cheddar cheese made with EPS-producing Lb. plantarum JLK0142 as an adjunct or its purified EPS as an ingredient. Our findings demonstrated that use of this strain and its EPS improved moisture retention, proteolysis, and microbiological characteristics, as well as textural and sensory proper- ties of low-fat Cheddar cheese. The cheese made with Lb. plantarum JLK0142 or its EPS as an ingredient also exhibited significantly increased antioxidant activity and inhibition on $\alpha$-amylase, $\alpha$-glucosidase, ACE, and tumor growth compared with the control cheese without use of this strain or EPS. However, correlations of the improved bioactivities of the cheese with the use of the EPS and proteolysis activities of $L b$. plantarum JLK0142 and the related molecular mechanisms need to be further studied. The results of this study suggest that the use of EPS-producing Lb. plantarum JLK0142 is a novel approach for improvement of both the ripening characteristics and bioactivities of low-fat Cheddar cheese.

\section{ACKNOWLEDGMENTS}

This work was supported by Jilin Provincial Education Department Science and Technology Research Project (Jilin, China; No. JJKH20170300KJ) and National Natural Science Foundation of China (Beijing, China; Grant No. 31601488).

\section{REFERENCES}

Abadía-García, L., A. Cardador, S. T. Martín del Campo, S. M. Arvízu, E. Castaño-Tostado, C. Regalado-González, B. GarcíaAlmendarez, and S. L. Amaya-LIano. 2013. Influence of probiotic strains added to cottage cheese on generation of potentially antioxidant peptides, anti-listerial activity, and survival of probiotic microorganisms in simulated gastrointestinal conditions. Int. Dairy J. 33:191-197.

Ahmed, N. H., M. El Soda, A. N. Hassan, and J. Frank. 2005. Improving the textural properties of an acid-coagulated (Karish) cheese using exopolysaccharide producing cultures. Lebensm. Wiss. Technol. 38:843-847.

Al-Dhaheri, A. S., R. Al-Hemeiri, J. Kizhakkayil, A. Al-Nabulsi, A. Abushelaibi, N. P. Shah, and M. Ayyash. 2017. Health-promoting benefits of low-fat akawi cheese made by exopolysaccharide-producing probiotic Lactobacillus plantarum isolated from camel milk. J. Dairy Sci. 100:7771-7779.

Amelia, I., M. A. Drake, B. Nelson, and D. M. Barbano. 2013. A new method for the production of low-fat Cheddar cheese. J. Dairy Sci. 96:4870-4884.

AOAC International. 2005. Official Methods of Analysis. 922.06. AOAC International, Arlington, VA.

Ayyash, M., B. Abu-Jdayil, F. Hamed, and R. Shaker. 2018. Rheological, textural, microstructural and sensory impact of exopolysaccharide-producing Lactobacillus plantarum isolated from camel milk on low-fat akawi cheese. Lebensm. Wiss. Technol. 87:423-431.

Ayyash, M. M., F. Sherkat, and N. P. Shah. 2012. The effect of NaCl substitution with $\mathrm{KCl}$ on Akawi cheese: Chemical composition, proteolysis, angiotensin-converting enzyme-inhibitory activity, probiotic survival, texture profile, and sensory properties. J. Dairy Sci. 95:4747-4759.

Bernabucci, U., E. Catalani, L. Basiricò, P. Morera, and A. Nardone. 2014. In vitro ACE-inhibitory activity and in vivo antihypertensive effects of water-soluble extract by Parmigiano Reggiano and Grana Padano cheeses. Int. Dairy J. 37:16-19.

Bintsis, T., and R. K. Robinson. 2004. A study of the effects of adjunct cultures on the aroma compounds of Feta-type cheese. Food Chem. $88: 435-441$. 
Blaya, J., Z. Barzideh, and G. LaPointe. 2018. Symposium review: Interaction of starter cultures and nonstarter lactic acid bacteria in the cheese environment. J. Dairy Sci. 101:3611-3629.

Bujalance, C., M. Jimenez-Valera, E. Moreno, and A. Ruiz-Bravo. 2006. A selective differential medium for Lactobacillus plantarum. J. Microbiol. Methods 66:572-575.

Di Cagno, R., I. D. Pasquale, M. D. Angelis, S. Buchin, C. G. Rizzello, and M. Gobbetti. 2014. Use of microparticulated whey protein concentrate, exopolysaccharide-producing Streptococcus thermophilus, and adjunct cultures for making low-fat Italian Caciotta-type cheese. J. Dairy Sci. 97:72-84.

Costa, N. E., J. A. Hannon, T. P. Guinee, M. A. E. Auty, P. L. H. McSweeney, and T. P. Beresford. 2010. Effect of exopolysaccharide produced by isogenic strains of Lactococcus lactis on half-fat Cheddar cheese. J. Dairy Sci. 93:3469-3486.

Cruz, A. G., F. C. A. Buriti, C. H. Souza, J. A. F. Faria, and S. M. I. Saad. 2009. Probiotic cheese: Health benefits, technological and stability aspects. Trends Food Sci. Technol. 20:344-354.

Dabour, N., E. E. Kheadr, N. Benhamou, I. Fliss, and G. LaPointe. 2006. Improvement of texture and structure of reduced-fat Cheddar cheese by exopolysaccharide-producing lactococci. J. Dairy Sci. 89:95-110.

Dabour, N., E. E. Kheadr, I. Fliss, and G. La Pointe. 2005. Impact of ropy and capsular exopolysaccharide-producing strains of Lactococcus lactis ssp. cremoris on reduced-fat Cheddar cheese production and whey composition. Int. Dairy J. 15:459-471.

Demers-Mathieu, V., D. St-Gelais, J. Audy, E. Laurin, and I. Fliss. 2016. Effect of the low-fat Cheddar cheese manufacturing process on the viability of Bifidobacterium animalis ssp. lactis, Lactobacillus rhamnosus, Lactobacillus paracasei/casei, and Lactobacillus plantarum isolates. J. Funct. Foods 24:327-337.

Dilna, S. V., H. Surya, R. G. Aswathy, K. K. Varsha, D. N. Sakthikumar, A. Pandey, and K. M. Nampoothiri. 2015. Characterization of an exopolysaccharide with potential health-benefit properties from a probiotic Lactobacillus plantarum RJF4. Lebensm. Wiss. Technol. 64:1179-1186.

Donkor, O. N., A. Henriksson, T. K. S. Vasiljevic, and N. P. Shah. 2007. ACE-inhibitory activity of probiotic yoghurt. Int. Dairy J. 17:1321-1331.

Fox, P. F. 1963. Potentiometric determination of salt in cheese. J. Dairy Sci. 46:744-745.

Ganesan, B., K. Brown, D. A. Irish, C. Brothersen, and D. J. McMahon. 2014. Manufacture and sensory analysis of reduced- and lowsodium Cheddar and Mozzarella cheeses. J. Dairy Sci. 97:19701982.

Hou, J., J. A. Hannon, P. L. H. McSweeney, T. P. Beresford, and T. P. Guinee. 2014. Effect of curd washing on cheese proteolysis, texture, volatile compounds, and sensory grading in full fat Cheddar cheese. Int. Dairy J. 34:190-198.

Khanal, B. K. S., B. Bhandari, S. Prakash, D. Liu, P. Zhou, and N. Bansal. 2018. Modifying textural and microstructural properties of low fat Cheddar cheese using sodium alginate. Food Hydrocoll. 83:97-108.

Kuchroo, C., and P. F. Fox. 1982. Soluble nitrogen in cheddar cheese: Comparison of extraction procedures. Milchwissenschaft 37:331335.

Li, S., Y. Zhao, L. Zhang, X. Zhang, L. Huang, D. Li, C. Niu, Z. Yang, and Q. Wang. 2012. Antioxidant activity of Lactobacillus plantarum strains isolated from traditional Chinese fermented foods. Food Chem. 135:1914-1919.

Liu, C., L. Fang, W. Min, J. Liu, and H. Li. 2018a. Exploration of the molecular interactions between angiotensin-I-converting enzyme (ACE) and the inhibitory peptides derived from hazelnut (Corylus heterophylla Fisch.). Food Chem. 245:471-480.

Liu, L., X. Qu, Q. Xia, H. Wang, P. Chen, X. Li. Wang, and W. Yang. 2018b. Effect of Lactobacillus rhamnosus on the antioxidant activity of Cheddar cheese during ripening and under simulated gastrointestinal digestion. Lebensm. Wiss. Technol. 95:99-106.

Liu, Z., Z. Zhang, L. Qiu, F. Zhang, X. Xu, H. Wei, and X. Tao. 2017. Characterization and bioactivities of the exopolysaccharide from a probiotic strain of Lactobacillus plantarum WLPL04. J. Dairy Sci. 100:6895-6905.

Lynch, K. M., P. L. H. McSweeney, E. K. Arendt, T. Uniacke-Lowe, S. Galle, and A. Coffey. 2014. Isolation and characterisation of exopolysaccharide-producing Weissella and Lactobacillus and their application as adjunct cultures in Cheddar cheese. Int. Dairy J. 34:125-134.

Madkor, S. A., P. S. Tong, and M. El Soda. 2000. Ripening of Cheddar cheese with added attenuated adjunct cultures of Lactobacilli. J. Dairy Sci. 83:1684-1691.

McSweeney, P. L. H. 2004. Biochemistry of cheese ripening. Int. J. Dairy Technol. 57:127-144.

Milesi, M. M., G. Vinderola, N. Sabbag, C. A. Meinardi, and E. Hynes. 2009. Influence on cheese proteolysis and sensory characteristics of non-starter lactobacilli strains with probiotic potential. Food Res. Int. 42:1186-1196.

O'Donovan, C. M., M. G. Wilkinson, T. P. Guinee, and P. F. Fox. 1996. An investigation of the autolytic properties of three lactococcal strains during cheese ripening. Int. Dairy J. 6:1149-1165.

Oluk, A. C., M. Güven, and A. A. Hayaloglu. 2014. Proteolysis texture and microstructure of low-fat Tulum cheese affected by exopolysaccharide-producing cultures during ripening. Int. J. Food Sci. Technol. 49:435-443.

Patten, D. A., S. Leivers, M. J. Chadha, M. Mohammed, P. N. Humphreys, A. P. Laws, and A. Collett. 2014. The structure and immunomodulatory activity on intestinal epithelial cells of the EPSs isolated from Lactobacillus helveticus sp. Rosyjski and Lactobacillus acidophilus sp. 5e2. Carbohydr. Res. 384:119-127.

Rajoka, M. S. R., M. Jin, H. Zhao, Q. Li, D. Shao, C. Jiang, Q. Huang, H. Yang, and J. Shi. 2018. Functional characterization and biotechnological potential of exopolysaccharide produced by Lactobacillus rhamnosus strains isolated from human breast milk. Lebensm. Wiss. Technol. 89:638-647.

Romeih, E. A., K. M. Moe, and S. Skeie. 2012. The influence of fat globule membrane material on the microstructure of low-fat Cheddar cheese. Int. Dairy J. 26:66-72.

Ryan, P. M., Z. Burdíková, T. Beresford, M. A. E. Auty, G. F. Fitzgerald, R. P. Ross, J. J. Sheehan, and C. Stanton. 2015. Reduced-fat Cheddar and Swiss-type cheeses harboring exopolysaccharide-producing probiotic Lactobacillus mucosae DPC 6426. J. Dairy Sci. 98:8531-8544.

Sasikumar, K., D. K. Vaikkath, L. Devendra, and K. M. Nampoothiri. 2017. An exopolysaccharide (EPS) from a Lactobacillus plantarum BR2 with potential benefits for making functional foods. Bioresour. Technol. 241:1152-1156.

Soda, M. E. 2014. Production of low fat Cheddar cheese made using exopolysaccharide-producing cultures and selected ripening cultures. Adv. Microbiol. 4:986-995.

Solieri, L., G. S. Rutella, and D. Tagliazucchi. 2015. Impact of nonstarter lactobacilli on release of peptides with angiotensin-converting enzyme inhibitory and antioxidant activities during bovine milk fermentation. Food Microbiol. 51:108-116.

Sousa, M. J., Y. Ardö, and P. L. H. McSweeney. 2001. Advances in the study of proteolysis during cheese ripening. Int. Dairy J. 11:327345

Stuknyte, M., S. Cattaneo, F. Masotti, and D. I. Noni. 2015. Occurrence and fate of ACE-inhibitor peptides in cheeses and in their digestates following in vitro static gastrointestinal digestion. Food Chem. 168:27-33.

Wang, J., K. Du, L. Fang, C. Liu, W. Min, and J. Liu. 2018b. Evaluation of the antidiabetic activity of hydrolyzed peptides derived from Juglans mandshurica Maxim fruits in insulin-resistant HepG2 cells and type 2 diabetic mice. J. Food Biochem. 42:e12518.

Wang, J., X. Fang, T. Wu, W. Min, and Z. Yang. 2018c. Exopolysaccharide producing Lactobacillus plantarum SKT109 as adjunct culture in Cheddar cheese production. Lebensm. Wiss. Technol. 97:419-426.

Wang, J., T. Wu, X. Fang, W. Min, and Z. Yang. 2018a. Characterization and immunomodulatory activity of an exopolysaccharide produced by Lactobacillus plantarum JLK0142 isolated from fermented dairy tofu. Int. J. Biol. Macromol. 115:985-993. 
Wang, J., X. Zhao, Z. Tian, Y. Yang, and Z. Yang. 2015b. Characterization of an exopolysaccharide produced by Lactobacillus plantarum YW11 isolated from Tibet Kefir. Carbohydr. Polym. $125: 16-25$

Wang, J., X. Zhao, Y. Yang, A. Zhao, and Z. Yang. 2015a. Characterization and bioactivities of an exopolysaccharide produced by Lactobacillus plantarum YW32. Int. J. Biol. Macromol. 74:119-126.

Wang, J., Z. Zheng, X. Zhao, Y. Yang, and Z. Yang. 2015c. Effect of starter cultures on the ripening properties of yak milk cheese. Food Sci. Technol. Res. 21:419-430.

Wang, K., W. Li, X. Rui, X. Chen, M. Jiang, and M. Dong. 2014 Characterization of a novel exopolysaccharide with antitumor activity from Lactobacillus plantarum 70810. Int. J. Biol. Macromol. 63:133-139.

Wang, X., C. Shao, L. Liu, X. Guo, Y. Xu, and X. Lü. 2017. Optimization, partial characterization and antioxidant activity of an exopolysaccharide from Lactobacillus plantarum KX041. Int. J. Biol. Macromol. 103:1173-1184.

Ye, X. P., C. Q. Song, P. Yuan, and R. G. Mao. 2010. a-Glucosidase and $\alpha$-amylase inhibitory activity of common constituents from traditional Chinese medicine used for diabetes mellitus. Chin. J. Nat. Med. 8:349-352.

Zhang, J., Y. Cao, J. Wang, X. Guo, Y. Zheng, W. Zhao, X. Mei, T. Guo, and Z. Yang. 2016. Physicochemical characteristics and bioactivities of the exopolysaccharide and its sulphated polymer from Streptococcus thermophilus GST-6. Carbohydr. Polym. 146:368-375.

Zhang, L., C. Liu, D. Li, Y. Zhao, X. Zhang, X. Zeng, X. Zeng, and Z. Yang. 2013a. Antioxidant activity of an exopolysaccharide isolated from Lactobacillus plantarum C88. Int. J. Biol. Macromol. $54: 270-275$

Zhang, L., X. Zhang, C. Liu, C. Li, S. Li, T. Li, Y. Zhao, and Z. Yang. 2013b. Manufacture of Cheddar cheese using probiotic Lactobacil lus plantarum K25 and its cholesterol-lowering effects in a mice model. World J. Microbiol. Biotechnol. 29:127-135.

Zisu, B., and N. P. Shah. 2007. Texture characteristics and pizza bake properties of low-fat Mozzarella cheese as influenced by pre-acidification with citric acid and use of encapsulated and ropy exopolysaccharide producing cultures. Int. Dairy J. 17:985-997. 